\title{
The use of audio-visual media in improving culinary students learning outcomes in chicken carcass material
}

\author{
Mashudi Mashudi *, Kokom Komariah, Moh. Farizqo Irvan \\ Universitas Negeri Yogyakarta. \\ Jl. Colombo No.1, Caturtunggal, Depok, Sleman, Daerah Istimewa Yogyakarta 55281, Indonesia. \\ * Corresponding Author. Email: mashudi.2018@student.uny.ac.id
}

ARTICLE INFO

Article History

Received:

11 December 2020;

Revised:

30 December 2020;

Accepted:

14 January 2021;

Available online:

14 June 2021

\section{Keywords}

Audio-visual;

Chicken carcass;

Culinary students;

Learning outcomes

\begin{abstract}
This research aimed to find out the effectiveness of audio-visual media (picture, video, audio) on culinary students' learning outcomes in chicken carcass material. The researcher implemented a quasiexperimental method with a nonequivalent control group design. The subjects of this study were the 10th-grade students of SMK Negeri 8 Medan, Academic Year 2016/2017. Cluster random sampling was applied in this study, which consisted of one experimental class and one control class. Meanwhile, some hypothetical tests used in this study were $\mathrm{n}$-gain, independent $\mathrm{t}$-test, and dependent $\mathrm{t}$-test. The $\mathrm{n}$-gain score of learning outcomes in the experimental class is higher than the control class, which is 0.5 and categorized as moderate. Furthermore, students' learning outcomes between those taught using audio-visual media and without audio-visual media in chicken carcass material indicated a significant difference with a significance score of $0.000 \leq$ 0.05 . Thus, the audiovisual media effectively improves the learning outcomes of the 10th-grade students of the culinary department in Chicken Carcass material.
\end{abstract}

This is an open access article under the CC-BY-SA license.

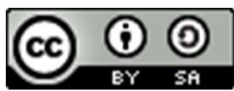

How to cite:

Mashudi, M., Komariah, K., \& Irvan, M. F. (2021). The use of audio-visual media in improving culinary students learning outcomes in chicken carcass material. Jurnal Pendidikan Vokasi, 11(1), 14-23. https://doi.org/10.21831/jpv.v11i1.36439

\section{INTRODUCTION}

The rapid development of technology in the industrial revolution 4.0 era significantly impacted each aspect of life, including education. The education system in the industrial revolution 4.0 era has a special characteristic that differentiates it from the previous education systems, especially in the learning process. In the industrial revolution 4.0 era, technology is utilized in each learning process (Lase, 2019). It can be implied that the learning process should move from conventional learning to technology-based learning.

Some learning resources that can be accessed due to the development of technology impact the perception that the teacher is not the only learning source. The changes in the learning pattern from teacher-centered into student-centered in curriculum 2013 have demanded the students to search for various information more actively in the learning process. In addition, the current learning system has implemented context-based learning that aims to correlate the learning material with students' daily life. In accommodating the changes in the learning system, the teachers need a medium for delivering the learning material effectively, such as technology-based learning media. 
However, based on the results of preliminary interviews with teachers at SMK Negeri 8 Medan, it is known that in the learning process, teachers still apply conventional methods. The facilities provided in the laboratory, such as computers and LCDs, have not been fully utilized in the learning process. This has an impact on low student achievement. The results of student exams on the chicken carcass material were not satisfactory because the number of students who passed the Minimum Completeness Criteria (KKM) was only 14 students, or only $41 \%$ of the total students in the class (34 students). This is evidenced by the results of interviews with students who stated that they still had difficulty distinguishing some parts of the chicken carcass and how to cut them properly and appropriately. In connection with this information, appropriate media is needed that can meet the needs of students. An alternative media used in student culinary learning is audiovisual media, especially on chicken carcass material.

Culinary is one of the majors provided at SMK. Culinary majors students have the same learning characteristics as students at other SMK. The learning system in SMK emphasizes mastery of learning material and practicum as basic knowledge for students when entering the real world of work. It is in line with Budiman, Soesanto, and Widjanarko (2017), which states that SMK emphasizes the ability to master knowledge, skills, attitudes, and several values in the real world. Therefore, several media are needed in the learning process because the learning system is dominated by practice to support the practical fieldwork process, and students can achieve goals systematically Arfika and Chalid (2017). One of the learning media that can be used to accommodate student needs is audiovisual media. Ashaver and Igyuve (2013); Olube (2015) specifically defines audiovisual media as media in software and hardware, which can increase student motivation in the learning process supported by instructions on the media. There are two main elements in audiovisual media, namely audio and visual elements (Desrianti et al., 2011). Hughes, Costley, and Lange (2019) stated that audio and visual elements in audiovisual media could accommodate the information needed by students and the effectiveness of learning with several stimuli. The stimulus can help students understand the material easily. Based on the research results, audiovisual media positively affects student learning outcomes on chicken carcass material.

Therefore, some audiovisual media have been developed for teaching chicken carcass material. Audiovisual media belong to a group of media that can visualize the material and provide sound at the same time (Rupawati et al., 2017). The term audiovisual refers to the instructional media that can be used in delivering meaning without any interdependence with the symbol or language (Anzaku, 2011). The learning materials in audiovisual media are related to the information about material and tools, system, or the information that can be practiced since the instructions are provided. Audiovisual media play several roles in the learning process, such as emphasizing the lessons obtained from experience-enhancing students' experiences, attracting students' participation, stimulating students' motivation, doing the instruction independently since it contains the source of information, and creating meaningful learning (Ashaver \& Igyuve, 2013). These important roles of audiovisual media are in line with (Chieke et al., 2017). In general, acquiring information is mostly dominated by visual and hearing senses (visualization and audio).

The effectiveness of audiovisual media in improving students' learning outcomes had been conducted by Sugiani, Syahbudi, and Handayani (2020) by using audiovisual media in teaching the students of the mechanical engineering department, and the results of the research proved that audiovisual medium was effective in improving students' learning outcomes. In addition, the research conducted by (Seçer et al., 2015) had also proved that using audiovisual media in the learning process can give a positive result in improving students' motivation, as well as resulting in positive learning outcome. Ode (2014) stated that in improving students' learning motivation by using audiovisual media, the abstract concept could be turned into the concrete ones. The students can understand the material easily. In addition, by using audiovisual media, the students can enjoy the learning process better (Kausar, 2013).

Based on the background, this study focused on identifying the effectiveness of audiovisual media in improving students' learning outcomes at the tenth-grade students of Culinary Department, in chicken carcass material. This research aimed to contribute to the culinary teachers in obtaining a reference related to the effective learning media for supporting the culinary teaching and learning process. Furthermore, the audiovisual medium can be used as the reference in chicken carcass 
material to enhance innovations in the learning process. By using suitable media, hopefully, can have positive influences on students' learning outcomes.

\section{RESEARCH METHOD}

The researchers implemented qualitative research by using a quasi-experimental method. The students in the experimental class received treatment, such as using audio-visual media in the learning process of chicken carcass material. The treatment was applied in order to identify whether there is a difference in students' learning outcomes between those who were taught using audiovisual media and those who were taught without using audio-visual media in chicken carcass material. The design of this quasi-experimental research was a Nonequivalent Control Group Design. However, only post-test scores in both classes were analyzed. The quasi-experimental research designs by using Control Group Design are shown in Table 1.

Table 1. Experimental Research Design

\begin{tabular}{cccc}
\hline Class & Pretest & Treatment & Posttest \\
\hline Control & $\mathrm{LO}_{1}$ & Student Textbook & $\mathrm{LO}_{2}$ \\
Experimental & $\mathrm{LO}_{1}$ & Audio-Visual Media & $\mathrm{LO}_{3}$ \\
\hline
\end{tabular}

There were two variables used in this research, namely independent variable and dependent variable. The independent variable in this research was the medium used in the experimental class (audio-visual media in teaching chicken carcass material). Meanwhile, the dependent variable in this study is the learning outcome of the tenth graders of the Culinary Department. This research was conducted in the even semester, the academic year 2016/2017. The population of this research was the tenth-grade students of the Culinary Department at SMK Negeri 8 Medan, Indonesia, with a total number of 172 students. More details can be seen in Table 2 .

Table 2. Research Population

\begin{tabular}{ccc}
\hline No. & Class & Total \\
\hline 1 & $\mathrm{X}^{1}$ & 36 \\
2 & $\mathrm{X}^{2}$ & 34 \\
3 & $\mathrm{X}^{3}$ & 36 \\
4 & $\mathrm{X}^{4}$ & 33 \\
5 & $\mathrm{X}^{5}$ & 33 \\
& Total number & 172 \\
\hline
\end{tabular}

Source: Administration SMK Negeri 8 Medan in Academic Year 2016

Based on Table 2, the sample used two classes. The classes used as the study subjects consisted of one experimental and one control class, selected using random cluster sampling (Azwar, 2010). There were 33 students (11 males and 22 females) in X-5 as the control class, while 33 students (12 males and 21 females) in X-4 belong to the experimental class. The students in the experimental class were taught using audio-visual media as the treatment in chicken carcass material, while the students in the control class were taught conventionally by using a student textbook in chicken carcass material. The data were collected by implementing two techniques, namely documentation, and tests. Documentations were used to identify students' initial ability based on the data of students' learning outcomes obtained from the teacher. Meanwhile, in measuring students' learning outcomes, several tests were applied. The test consisted of 38 items in the form of multiple choices. In addition, the test of validity and reliability of the instrument had been conducted empirically. The treatments were conducted in four meetings, while the tests were conducted before and after the treatment.

The data were analyzed by using qualitative and quantitative methods. Data analysis using the quantitative method was conducted by applying the n-gain test to identify the category of 
students' learning improvement. Meanwhile, data analysis using the quantitative method was conducted by applying an independent t-test, comparing the students' scores in the post-tests, both experimental and control classes; and a dependent t-test was used to compare students' scores before and after the treatment given. Before applying the t-test, prerequisite tests must be conducted, such as normality and homogeneity test. If the two prerequisites have met the criteria, a t-test can be conducted. Independent and dependent t-test are met if the $\alpha \leq 0.05$. As a result, it can be concluded that there is a significant difference in students' learning outcomes between the students in experimental and control classes.

\section{RESULT AND DISCUSSION}

The results of the descriptive analysis of the frequency distribution on the post-test scores of the control class and the experimental class can be seen in Table 3 .

Table 3. Frequency Distribution Table of Experimental Class Post-Test Result

\begin{tabular}{cccc}
\hline No. Class & Interval Class & Frequency & Frekuensi Relatif $(\%)$ \\
\hline 1 & $68-71$ & 1 & 3,03 \\
2 & $72-75$ & 4 & 12,12 \\
3 & $76-79$ & 12 & 36,36 \\
4 & $80-83$ & 6 & 18,18 \\
5 & $84-87$ & 7 & 21,21 \\
6 & $88-91$ & 3 & 9,09 \\
& & 33 & 100 \\
\hline
\end{tabular}

Based on Table 3, the results show that 33 students had the highest score of 91 and the lowest score was 68 with an average $(\mathrm{M})=80.54$ and a standard deviation $(\mathrm{Sd})=4.75$. The frequency distribution of the group learning outcomes using carcass audio-visual media was the highest in the 76-79 interval class at 36.36 percent.

Table 4. Frequency Distribution Table Control Class Post-Test Result

\begin{tabular}{cccc}
\hline No. Class & Interval Class & Frequency & Frekuensi Relatif (\%) \\
\hline 1 & $50-53$ & 3 & 9,09 \\
2 & $54-57$ & 4 & 12,12 \\
3 & $58-61$ & 12 & 36,36 \\
4 & $62-65$ & 7 & 21,21 \\
5 & $66-69$ & 5 & 15,15 \\
6 & $70-73$ & 2 & 6,06 \\
& Jumlah & 33 & 100 \\
\hline
\end{tabular}

(Source: Primary Data, 2016)

Based on Table 4, the results showed that 33 students had the highest score of 71 and the lowest score of 50 with an average $(\mathrm{M})=60.93$ and standard deviation $(\mathrm{Sd})=5.22$. The frequency distribution of the group learning outcomes using Carcass Audio-Visual Media was the highest in the 58-61 interval class at 36.36 percent. The difference in students' learning outcomes can be identified from students' mean scores in both classes, before and after the treatment. The comparison results indicated that students' scores in the experimental class taught using audio-visual media in Chicken Carcass material are higher than students' scores in the control class. The results of the pre-test and post-test in both classes are shown in Table 5.

Based on Table 5, there is an improvement in students' learning outcomes in both classes. However, the improvement is varied, based on the classes. In the experimental class, students' learning improvement was counted as 19.67 , while the value of n-gain was 0.50 and categorized as moderate. Meanwhile, students in the control class improved, and it was 3.85, while the value of n- 
gain was 0.09 , categorized as low. The graph of student learning outcomes in the experimental and control class can be seen in Figure 1.

Table 5. Results of Student's Learning Outcomes based on of Pretest and Post-test Scores

\begin{tabular}{clcccc}
\hline \multirow{2}{*}{ No. } & \multirow{2}{*}{ Group of Class } & \multicolumn{2}{c}{ Mean } & \multirow{2}{*}{ N-Gain } & \multirow{2}{*}{ Category } \\
\hline 1 & Control & 57.12 & 60.93 & 0.09 & Low \\
2 & Experimental & 60.87 & 80.54 & 0.50 & Moderate \\
\hline
\end{tabular}

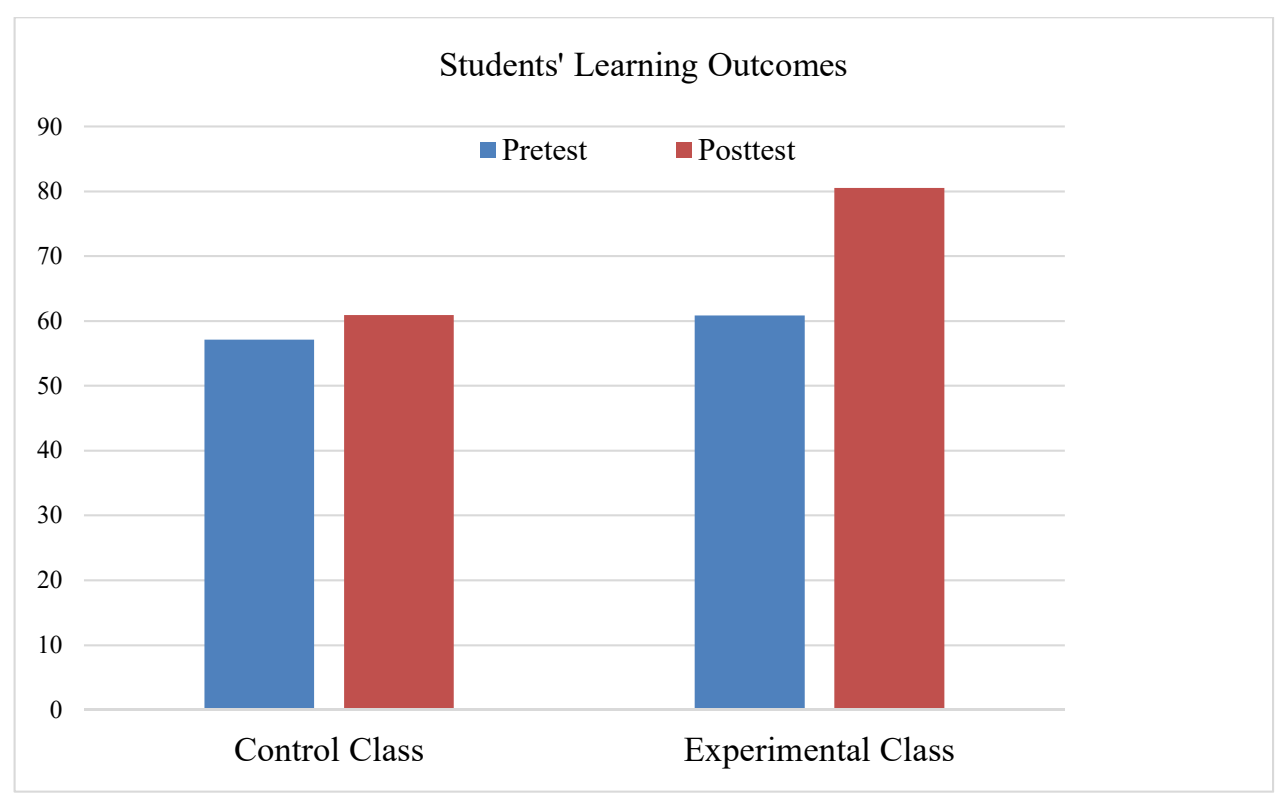

Figure 1. Students' Learning Outcomes in Both Classes

Based on Figure 1, there are no improvements in students' learning outcomes in both classes, before and after the treatment. After that, to calculate the significance of students' learning outcomes, a dependent t-test should be applied. Based on the dependent t-test, students' learning outcomes in experimental class before and after the treatment of using audio-visual media in Chicken Carcass material indicate a significant difference. Meanwhile, students learning outcomes in the control class, both before and after the treatment, did not indicate any significant difference. The calculation results of the dependent $t$-test in identifying the significant difference in the students' learning outcomes before and after the treatment in both classes are as presented in Table 6.

Table 6. Results of The Paired t-Test

\begin{tabular}{clccc}
\hline No. & Group of Class & Sig. (2-tailed) & Hypothesis & Explanation \\
\hline 1 & Control & 0.060 & $(0.060<0.05)$ & Not Significant \\
2 & Experimental & 0.000 & $(0.000<0.05)$ & Significant \\
\hline
\end{tabular}

Based on Table 6, it can be seen that the significant value in the control class is higher than $0.05(\alpha>0.05)$, and it can be concluded that there is no significant difference in students' learning outcomes before and after the treatment given. Meanwhile, in the experimental class, the significance value was lower than $0.05(\alpha<0.05)$. It can be concluded that there is a significant difference in students' learning outcomes before and after the treatment given.

After identifying the difference in students' learning outcomes before and after the treatment in both classes, the next step is identifying students' learning outcomes in both classes. The effectiveness of audio-visual media in teaching Chicken Carcass material can be seen from students' learning outcomes in both classes by applying an independent $t$-test. The results of the independent t-test are as presented in Table 7. 
Table 7. Results of Independent Sample t-Test

\begin{tabular}{cccc}
\hline Group of Class & Sig. $(2$-tailed) & Hypothesis & Explanation \\
\hline Control Experimental & 0.000 & $(0.000<0.05)$ & Significant \\
\hline
\end{tabular}

Based on Table 7, it can be seen that the significance score is higher than $0.05(0.000<$ 0.05 ), and it can be concluded that there is a significant difference in students' mean scores between the students in the experimental class who were taught using audio-visual media in chicken carcass material, and students in control class who were taught without using audio-visual media in chicken carcass material. As a result, audio-visual media significantly influence students' learning outcomes in chicken carcass material. In other words, audio-visual media effectively improves students' learning outcomes at the tenth-grade students of the Culinary Department. Several components influence successful learning. Felinda and Sugiyono (2018) said that several learning processes are learning objective, learning material, learning method, model, strategy, media, and the evaluation conducted in the learning system. These aspects are correlated to each other in the learning process (Dolong, 2016). The teacher plays an important role in combining aspects to create suitability in the learning process that impacts learning success.

One of the important components in the learning process is the learning medium. The learning medium aims to support the learning process to stimulate students' thoughts, feeling, attention, and skill, and the learning process can be acquired (Tafonao, 2018). Pane and Dasopang (2017) stated that the learning medium has functioned as an effective and efficient tool for achieving the learning objective. Thus, in determining the learning medium, it should be considered carefully. Lee (2016) stated that it should construct reality and correlate with the ongoing learning material in determining the learning medium. In addition, the learning process should meet teachers' and students' needs to create a meaningful learning system Umar (2014). The choices of the learning media that meet teachers' and students' needs are dynamic. The media's critical point is to accommodate students' needs based on the learning objective, students' characteristics, and learning material (Abidin, 2016).

Audio-visual media in teaching chicken carcass material can be seen in Figure 2.

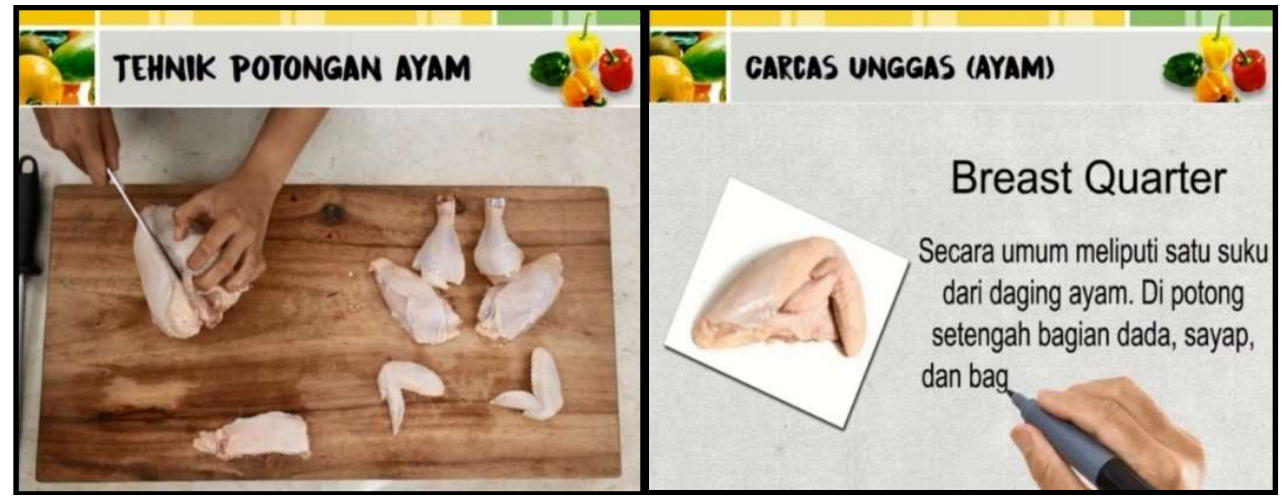

Figure 2. Chicken Carcass Audio-Visual Media

Several conditions support the use of audiovisual media in improving students' learning outcomes in chicken carcass. The conditions are related to some elements in audiovisual media, as follows:

First, audiovisual media consist of several visual elements. Learning media that consist of several visual elements impacts students' learning outcomes (Verhallen \& Bus, 2011). Ching-Han et al. (2016) stated that visual elements in the learning media could motivate and attract students' attention. In addition, the visual elements in learning media can help the students recall the materials easily (Amit et al., 2019). In addition, according to Dallacqua and Peralta (2019), visual elements contained in the learning media can help the students to understand the material easily. The visual elements can help students understand abstract concepts (Aukerman \& Chambers Schuldt, 2016; 
Shabiralyani et al., 2015). The students will understand the abstract concepts since the visual elements present the messages by using text. In addition, visual elements help the students understand the material and improve students' critical thinking skills (Raiyn, 2016).

Second, audiovisual media consist of some audio elements. Hardiah (2019) and Namaziandost et al. (2019) stated that audio elements in a learning medium could enhance students' listening skills. Good listening skills will impact students' good understanding of the learning process Widyaningrum (2015). Students that have a good understanding will have a good achievement as well. It is in line with the findings of the research conducted by Taylor and Clark (2010) and Curran and Seo (2018), which revealed that learning media with audio elements could improve students' learning outcomes.

Third, the audiovisual medium contains instructions for the learning process. According to Adekola (2010), instructional media aimed to provide information in the learning process in instructions. Using audiovisual media in teaching chicken carcass material can support the material on chicken cut shapes and cut the chicken into some parts. Using audiovisual media, students can identify the chicken cut shapes and the steps in cutting chicken as the food ingredients. Capuno et al. (2019) stated that instructional media significantly impact students' motivation to create meaningful learning. Sung et al. (2015) dan Vallori (2014) said that in meaningful learning, students could construct concepts and knowledge, and it will help the students memorize and understand the material easily. In addition, instructional media can improve students' participation and learning outcomes (Setyorini \& Churiyah, 2016).

\section{CONCLUSIONS}

This study indicated that students' mean scores in an experimental class taught using audiovisual media in chicken carcass material are higher than students' mean scores in the control class $(80.54>60.93)$ tenth-grade students of the Culinary Department. As a result, it can be concluded that audiovisual media effectively improves culinary vocational students' learning outcomes in Chicken Carcass material. However, even though the results of this study indicated that audio visual media are effective in audiovisual students' learning outcomes in Chicken Carcass material, there are several limitations found in this research. First, the number of samples was still limited, while to get comprehensive data, a more significant number of samples is required. Second, the material taught in this study was limited, and it was only taught on several basic competencies. Third, the researchers only focused on the cognitive domain, and for further researchers, it should be developed by adding other domains.

\section{REFERENCES}

Abidin, Z. (2016). Penerapan pemilihan media pembelajaran. Edcomtech : Jurnal Kajian Teknologi Pendidikan, 1(1), 9-20. http://journal2.um.ac.id/index.php/edcomtech/article/view/1784

Adekola, G. (2010). The impact of instructional media on the education of youths on HIV/AIDS in Nigeria urban communities. International Journal of Scientific Research in Education, 3(1), 64-72. https://www.semanticscholar.org/paper/The-Impact-of-Instructional-Media-on-theEducation-Adekola/db1d4685a76be1689de50176f34269e05fc09f6e?p2df

Amit, E., Rim, S. Y., Halbeisen, G., Cohen Priva, U., Stephan, E., \& Trope, Y. (2019). Distancedependent memory for pictures and words. Journal of Memory and Language, 105(December 2018), 119-130. https://doi.org/10.1016/j.jml.2019.01.001

Anzaku, F. (2011). Library experts speaks on audio-visual material. Lafia: United Nations Educational, Scientific and Cultured Organization (UNESCO) world day for audio-visual heritage.

Arfika, F., \& Chalid, S. (2017). Penerapan media berbasis video tutorial untuk meningkatkan hasil belajar membuat kampuh siswa kelas X SMK Negeri 1 Stabat. Jurnal Pendidikan Tata Busana, $1((1)), 30-38$. 
Ashaver, D., \& Igyuve, S. M. (2013). The use of audio-visual materials in the teaching and learning processes in colleges of education in Benue State-Nigeria. IOSR Journal of Research \& Method in Education (IOSRJRME), 1(6), 44-55. https://doi.org/10.9790/7388-0164455

Aukerman, M., \& Chambers Schuldt, L. (2016). "The Pictures Can Say More Things": Change Across Time in Young Children's References to Images and Words During Text Discussion. Reading Research Quarterly, 51(3), 267-287. https://doi.org/10.1002/rrq.138

Azwar, S. (2010). Metode penelitian. Pustaka Pelajar.

Budiman, F. A., Soesanto, S., \& Widjanarko, D. (2017). Pengembangan lembar kerja praktik analitik bagi calon guru SMK otomotif. Journal of Vocational and Career Education, 2(1), 50-56. https://doi.org/10.15294/jvce.v2i1.11104

Capuno, R., Revalde, H., Etcuban, J. O., Aventuna, M., Medio, G., \& Demeterio, R. A. (2019). Facilitating learning mathematics through the use of instructional media. International Electronic Journal of Mathematics Education, 15(1), 677-688. https://doi.org/10.29333/iejme/5785

Chieke, J. C., Ewelum, J. N., \& Madu, C. O. (2017). Determination of auditory and visual learning styles of adult learners in adult literacy centres in Anambra State, Nigeria. IOSR Journal of Research \& Method in Education (IOSR-JRME), 7(3), 30-33. https://doi.org/10.9790/73880703053033

Ching-Han, Y., Jui-Ching, C., \& Mei-Ju, C. (2016). Empowering children's creativity with the instruction of wordless picture books. European Journal of Research and Reflection in Educational Sciences, 4(7), 1-16. http://www.idpublications.org/wpcontent/uploads/2016/06/Full-Paper-EMPOWERING-CHILDRENS-CREATIVITY-WITHTHE-INSTRUCTION-OF-WORDLESS-PICTURE-BOOKS.pdf

Curran, A., \& Seo, K. K. (2018). Audio engagement and learning. American Journal of Distance Education, 32(4), 223-235. https://doi.org/10.1080/08923647.2018.1509266

Dallacqua, A. K., \& Peralta, L. R. (2019). Reading and (Re)writing science comics: a study of informational texts. Reading Teacher, 73(1), 111-118. https://doi.org/10.1002/trtr.1801

Desrianti, I. D., Rahardja, U., \& Mulyani, R. (2011). Audio visual as one of the teaching resources on llearning. CCIT (Creative Communication and Innovative Technology) Journal, 5(40), 124144. https://doi.org/10.33050/ccit.v5i2.145

Dolong, H. M. J. (2016). Teknik analisis dalam komponen pembelajaran. Jurnal Inspiratif Pendidikan, 5(2), 293-300. https://doi.org/10.24252/ip.v5i2.3484

Felinda, I., \& Sugiyono, S. (2018). Pembelajaran sejarah yang efektif di SMA negeri 1 Mlati Sleman. Istoria: Jurnal Pendidikan Dan Sejarah, 14(1), 91-106. https://doi.org/10.21831/istoria.v14i1.19426

Hardiah, M. (2019). Improving students listening skill by using audio visual media. Al-Lughah: Jurnal Bahasa, 7(2), 39-49. https://doi.org/10.29300/lughah.v7i2.1673

Hughes, C., Costley, J., \& Lange, C. (2019). The effects of multimedia video lectures on extraneous load. Distance Education, 40(1), 54-75. https://doi.org/10.1080/01587919.2018.1553559

Kausar, G. (2013). Students' perspective of the use of audio visual aids in Pakistan. International Proceedings of Economics Development and Research, 68(3), 73-77. https://doi.org/10.7763/IPEDR

Lase, D. (2019). Education and industrial revolution 4.0. JURNAL HANDAYANI PGSD FIP UNIMED, 10(1), 48-62. https://doi.org/10.24114/jh.v10i1.14138

Lee, A. Y. L. (2016). Media education in the School 2.0 era: Teaching media literacy through laptop computers and iPads. Global Media and China, 1(4), 435-449. 
https://doi.org/10.1177/2059436416667129

Namaziandost, E., Nasri, M., \& Akbari, S. (2019). The impact of teaching listening comprehension by audio and video aids on the intermediate efl learners listening proficiencies. Language, Literature and Culture, 2(3), 121-128.

Ode, E. O. (2014). Impact of audio-visual (AVs) resources on teaching and learning in some selected private secondary schools in Makurdi. International Journal of Research in Humanities, Arts and Literature (IMPACT: IJRHAL), 2(5), 195-202. http://paper.researchbib.com/view/paper/17613

Olube, F. K. (2015). Primary school pupils' response to audio-visual learning process in PortHarcourt. Journal of Education and Practice, 6(10), 118-123. https://eric.ed.gov/?id=EJ1081684

Pane, A., \& Dasopang, M. D. (2017). Belajar dan pembelajaran. FITRAH: JURNAL KAJIAN ILMUILMU KEISLAMAN, 3(2), 333-352. https://doi.org/10.24952/fitrah.v3i2.945

Raiyn, J. (2016). The role of visual learning in improving students' high-order thinking skills. Journal of Education and Practice, 7(24), 115-121. https://files.eric.ed.gov/fulltext/EJ1112894.pdf

Rupawati, D., Noviani, L., \& Nugroho, J. A. (2017). Penerapan media pembelajaran audio visual untuk meningkatkan hasil belajar ekonomi. Prosiding Seminar Pendidikan Ekonomi Dan Bisnis, 3(1), 21-30. https://jurnal.fkip.uns.ac.id/index.php/snpe/article/view/10638

Seçer, Ş. Y. E., Şahin, M., \& Alc1, B. (2015). Investigating the effect of audio visual materials as warm-up activity in aviation english courses on students' motivation and participation at high school level. Procedia - Social and Behavioral Sciences, 199, 120-128. https://doi.org/10.1016/j.sbspro.2015.07.495

Setyorini, D., \& Churiyah, M. (2016). Increasing activeness and learning outcomes by developing borland delphi 7.0 application as instructional Mmedia. Journal of Education and Practice, 7(14), 129-140. https://files.eric.ed.gov/fulltext/EJ1103038.pdf

Shabiralyani, G., Hasan, K. S., Hamad, N., \& Iqbal, N. (2015). Impact of visual aids in enhancing the learning process case research: District Dera Ghazi Khan. Journal of Education and Practice, 6(19), 226-233. https://files.eric.ed.gov/fulltext/EJ1079541.pdf

Sugiani, S., Syahbudi, I., \& Handayani, W. (2020). Comparison of audio-visual learning effectiveness with conventional media on student learning outcomes in the operation of lathe machine lesson for class XI students of SMK Private Satrya Budi I Perdagangan. International Journal of Resarch and Review, 7(3), 37-43. https://www.ijrrjournal.com/IJRR_Vol.7_Issue.3_March2020/IJRR005.pdf

Sung, H. Y., Hwang, G. J., \& Chang, H. S. (2015). An integrated contextual and web-based issue quest approach to improving students' learning achievements, attitudes and critical thinking. Educational Technology \& Society, 18(4), 299-311. http://www.jstor.org/stable/jeductechsoci.18.4.299

Tafonao, T. (2018). Peranan media pembelajaran dalam meningkatkan minat belajar mahasiswa. Jurnal Komunikasi Pendidikan, 2(2), 103-114. https://doi.org/10.32585/jkp.v2i2.113

Taylor, L., \& Clark, S. (2010). Educational design of short, audio-only podcasts: The teacher and student experience. Australasian Journal of Educational Technology, 26(3), 386-399. https://doi.org/10.14742/ajet.1082

Umar, U. (2014). Media pendidikan: Peran dan fungsinya dalam pembelajaran. Tarbawiyah: Jurnal Ilmiah Pendidikan, 11(1), 131-144. https://www.repository.metrouniv.ac.id/index.php/tarbawiyah/article/view/364

Vallori, A. B. (2014). Meaningful learning in practice. Journal of Education and Human 
Development, 3(4), 199-209. https://doi.org/10.15640/jehd.v3n4a18

Verhallen, M. J. A. J., \& Bus, A. G. (2011). Young second language learners' visual attention to illustrations in storybooks. Journal of Early Childhood Literacy, 11(4), 480-500. https://doi.org/10.1177/1468798411416785

Widyaningrum, H. K. (2015). Penggunaan media audio untuk meningkatkan kemampuan menyimak dongeng anak pada siswa kelas IV sekolah dasar. Premiere Educandum : Jurnal Pendidikan Dasar Dan Pembelajaran, 5(2), 200-209. https://doi.org/10.25273/pe.v5i02.284 